Cochrane Database of Systematic Reviews

\title{
Buprenorphine for neuropathic pain in adults (Review)
}

Wiffen PJ, Derry S, Moore RA, Stannard C, Aldington D, Cole P, Knaggs R

Wiffen PJ, Derry S, Moore RA, Stannard C, Aldington D, Cole P, Knaggs R.

Buprenorphine for neuropathic pain in adults.

Cochrane Database of Systematic Reviews 2015, Issue 9. Art. No.: CD011603.

DOI: 10.1002/14651858.CD011603.pub2.

www.cochranelibrary.com 
TABLE OF CONTENTS

ABSTRACT 1

PLAIN LANGUAGE SUMMARY

BACKGROUND

OBJECTIVES

METHODS

Figure 1.

RESULTS

DISCUSSION

AUTHORS' CONCLUSIONS

ACKNOWLEDGEMENTS

REFERENCES

CHARACTERISTICS OF STUDIES

APPENDICES

WHAT'S NEW

HISTORY

CONTRIBUTIONS OF AUTHORS

DECLARATIONS OF INTEREST

SOURCES OF SUPPORT

DIFFERENCES BETWEEN PROTOCOL AND REVIEW

NOTES

INDEX TERMS

1

3

5

5

6

7

8

8

8

10

15

15

17

17

17 
[Intervention Review]

\section{Buprenorphine for neuropathic pain in adults}

Philip J Wiffen ${ }^{1}$, Sheena Derry², R Andrew Moore ${ }^{3}$, Cathy Stannard4 ${ }^{4}$, Dominic Aldington 5 , Peter Cole 6 , Roger Knaggs 7

${ }^{1}$ Thame, UK. ${ }^{2}$ Oxford, UK. ${ }^{3}$ Plymouth, UK. ${ }^{4} \mathrm{NHS}$ Gloucestershire CCG, Brockworth, UK. ${ }^{5}$ Royal Hampshire County Hospital, Winchester, UK. ${ }^{6}$ Oxford Pain Relief Unit, Churchill Hospital, Oxford University Hospitals NHS Trust, Oxford, UK. ${ }^{7}$ School of Pharmacy, University of Nottingham, Nottingham, UK

Contact: R Andrew Moore, Plymouth, UK. andrew.moore@omkltd.org.

Editorial group: Cochrane Pain, Palliative and Supportive Care Group.

Publication status and date: Stable (no update expected for reasons given in 'What's new'), published in Issue 5, 2019.

Citation: Wiffen PJ, Derry S, Moore RA, Stannard C, Aldington D, Cole P, Knaggs R. Buprenorphine for neuropathic pain in adults. Cochrane Database of Systematic Reviews 2015, Issue 9. Art. No.: CD011603. DOI: 10.1002/14651858.CD011603.pub2.

Copyright @ 2019 The Cochrane Collaboration. Published by John Wiley \& Sons, Ltd.

\section{A B S T R A C T}

\section{Background}

Opioid drugs, including buprenorphine, are commonly used to treat neuropathic pain, and are considered effective by some professionals. Most reviews have examined all opioids together. This review sought evidence specifically for buprenorphine, at any dose, and by any route of administration. Other opioids are considered in separate reviews.

\section{Objectives}

To assess the analgesic efficacy of buprenorphine for chronic neuropathic pain in adults, and the adverse events associated with its use in clinical trials.

\section{Search methods}

We searched the Cochrane Central Register of Controlled Trials (CENTRAL), MEDLINE, and EMBASE from inception to 11 June 2015 , together with reference lists of retrieved papers and reviews, and two online study registries.

\section{Selection criteria}

We included randomised, double-blind studies of two weeks' duration or longer, comparing any oral dose or formulation of buprenorphine with placebo or another active treatment in chronic neuropathic pain.

\section{Data collection and analysis}

Two review authors independently searched for studies, extracted efficacy and adverse event data, and examined issues of study quality. We did not carry out any pooled analyses.

\section{Main results}

Searches identified 10 published studies, and one study with results in ClinicalTrials.gov. None of these 11 studies satisfied our inclusion criteria, and so we included no studies in the review.

\section{Authors' conclusions}

There was insufficient evidence to support or refute the suggestion that buprenorphine has any efficacy in any neuropathic pain condition.

\section{PLAIN LANGUAGE SUMMARY}

Buprenorphine for neuropathic pain in adults 
Neuropathic pain is pain coming from damaged nerves. It is different from pain messages that are carried along healthy nerves from damaged tissue (for example, a fall or cut, or arthritic knee). Neuropathic pain is often treated by different medicines (drugs) to those used for pain from damaged tissue, which we often think of as painkillers. Medicines that are sometimes used to treat depression or epilepsy can be very effective in some people with neuropathic pain. But sometimes opioid painkillers are used to treat neuropathic pain.

Opioid painkillers are drugs like morphine. Morphine is derived from plants, but many opioids are also made by chemical synthesis rather than being extracted from plants. Buprenorphine is one of these synthetic opioids. It is available in numerous countries for use as a painkiller, and can be given by injection, as a tablet placed under the tongue, or as a patch that delivers the drug to the body through the skin.

In June 2015, we performed searches to look for clinical trials where buprenorphine was used to treat neuropathic pain in adults. We found no study that did this, and that met our requirements for the review.

There is no evidence to support or refute the suggestion that buprenorphine works in any neuropathic pain condition. Large, properly conducted new clinical trials would be needed to provide evidence that buprenorphine worked in neuropathic pain conditions. 


\section{B A C K G R O U N D}

This review is based on a template for reviews of drugs used to relieve neuropathic pain. The aim is for all reviews to use the same methods, based on new criteria for what constitutes reliable evidence in chronic pain (Moore 2010a; Appendix 1).

\section{Description of the condition}

The 2011 International Association of the Study of Pain definition of neuropathic pain is "pain caused by a lesion or disease of the somatosensory system" (Jensen 2011), based on an earlier consensus meeting (Treede 2008). Neuropathic pain is a consequence of a pathological maladaptive response of the nervous system to 'damage' from a wide variety of potential causes. It is characterised by pain in the absence of a noxious stimulus and may be spontaneous (continuous or paroxysmal) in its temporal characteristics or be evoked by sensory stimuli (dynamic mechanical allodynia where pain is evoked by light touch of the skin). Neuropathic pain is associated with a variety of sensory loss (numbness) and sensory gain (allodynia) clinical phenomena, the exact pattern of which vary between patient and disease, perhaps reflecting different pain mechanisms operating in an individual patient and therefore potentially predictive of response to treatment (Demant 2014; Helfert 2015; von Hehn 2012). Pre-clinical research hypothesises a bewildering array of possible pain mechanisms that may operate in people with neuropathic pain, which largely reflect pathophysiological responses in both the central and peripheral nervous systems, including neuronal interactions with immune cells (Baron 2012; Calvo 2012; von Hehn 2012). Overall, the treatment gains in neuropathic pain, to even the most effective of available drugs, are modest (Finnerup 2015; Moore 2013a), and a robust classification of neuropathic pain is not yet available (Finnerup 2013).

Neuropathic pain is usually divided according to the cause of nerve injury. There may be many causes, but some common causes of neuropathic pain include diabetes (painful diabetic neuropathy $(\mathrm{PDN})$ ), shingles (postherpetic neuralgia $(\mathrm{PHN})$ ), amputation (phantom limb pain), neuropathic pain after surgery or trauma, stroke or spinal cord injury, trigeminal neuralgia, and human immunodeficiency virus (HIV) infection.

Many people with neuropathic pain conditions are significantly disabled with moderate or severe pain for many years. Chronic pain conditions comprised five of the 11 top-ranking conditions for years lived with disability in 2010 (Vos 2012), and are responsible for considerable loss of quality of life, employment, and increased healthcare costs (Moore 2014a).

In systematic reviews, the overall prevalence of neuropathic pain in the general population is reported to be between $7 \%$ and $10 \%$ (van Hecke 2014), and about $7 \%$ in a systematic review of studies published since 2000 (Moore 2014a). In individual countries, prevalence rates have been reported as 3.3\% in Austria (Gustorff 2008), 6.9\% in France (Bouhassira 2008), and up to $8 \%$ in the UK (Torrance 2006). Some forms of neuropathic pain, such as PDN and post-surgical chronic pain (which is often neuropathic in origin), are increasing (Hall 2008). The prevalence of PHN is likely to fall if vaccination against the herpes virus becomes widespread.

Estimates of incidence vary between individual studies for particular origins of neuropathic pain, often because of small numbers of cases. In primary care in the UK between 2002 and 2005 , the incidences (per 100,000 person-years' observation) were 28 (95\% confidence interval ( $\mathrm{Cl}) 27$ to 30 ) for PHN, 27 (26 to 29) for trigeminal neuralgia, 0.8 (0.6 to 1.1) for phantom limb pain, and 21 (20 to 22) for PDN (Hall 2008). However, the incidence of trigeminal neuralgia has also been estimated at 4 in 100,000 per year (Katusic 1991; Rappaport 1994), and 12.6 per 100,000 personyears for trigeminal neuralgia and 3.9 per 100,000 person-years for PHN in a study of facial pain in the Netherlands (Koopman 2009). One systematic review of chronic pain demonstrated that some neuropathic pain conditions, such as PDN, can be more common than other neuropathic pain conditions, with prevalence rates up to 400 per 100,000 person-years (McQuay 2007).

Neuropathic pain is known to be difficult to treat effectively, with only a minority of individuals experiencing a clinically relevant benefit from any one intervention. A multidisciplinary approach is now advocated, with pharmacological interventions being combined with physical or cognitive interventions, or both. Conventional analgesics are usually not effective, but without evidence to support or refute that view. Some people with neuropathic pain may derive some benefit from a topical lidocaine patch or low concentration topical capsaicin, though evidence about benefits is uncertain (Derry 2012; Derry 2014). High concentration topical capsaicin may benefit some people with PHN (Derry 2013). Treatment for neuropathic pain is more usually by so-called unconventional analgesics (pain modulators) such as antidepressants like duloxetine and amitriptyline (Lunn 2014; Moore 2012b; Sultan 2008), or antiepileptics like gabapentin or pregabalin (Moore 2009; Moore 2014b; Wiffen 2013).

The proportion of people who achieve worthwhile pain relief (typically at least 50\% pain intensity reduction; Moore 2013b) is small, generally only $10 \%$ to $25 \%$ more than with placebo, with numbers needed to treat for an additional beneficial outcome (NNT) usually between 4 and 10 (Kalso 2013; Moore 2013a). Neuropathic pain is not particularly different from other chronic pain conditions in that only a small proportion of trial participants have a good response to treatment (Moore 2013a).

The current National Institute for Health and Care Excellence (NICE) guidance suggests offering a choice of amitriptyline, duloxetine, gabapentin, or pregabalin as initial treatment for neuropathic pain (with the exception of trigeminal neuralgia), with switching if first, second, or third drugs tried are not effective or not tolerated (NICE 2013). This concurs with other recent guidance (Finnerup 2015).

\section{Description of the intervention}

Buprenorphine is a thebaine derivative opioid drug, classified as a step III opioid analgesic by the World Health Organization (WHO 1996). It has mixed agonistic and antagonistic properties, with opioid agonistic activity exerted on mu-opioid receptors and the ORL-1 receptor; it is a kappa- and delta-opioid receptor antagonist (Kress 2009; Pergolizzi 2010; Walsh 2003). Buprenorphine is metabolised predominantly by the liver and excreted in bile after de-alkylation and glucuronidation, though hepatic extraction from blood may be more complicated (Bullingham 1984). The pharmacokinetics of buprenorphine vary with route of administration. While the sublingual and intramuscular routes produce similar outcomes in terms of pain relief, when taken orally, buprenorphine undergoes extensive pre-systemic elimination (Bullingham 1981; Bullingham 1983). 
Buprenorphine is available in numerous countries for use as an analgesic, and can be given by injection, as a sublingual tablet, or as a transdermal patch (or plaster). Typical analgesic doses of buprenorphine are 0.3 to $0.6 \mathrm{mg}$ (intramuscular or intravenous) and its analgesic effects last about six hours. Sublingual buprenorphine doses are typically 200 to 400 micrograms $(\mu \mathrm{g})$ every six to eight hours. It is prescribed in the management of cancer pain, but not typically as a first-line opioid. It is also used in opioid-dependence (Foster 2013).

Oral bioavailability of buprenorphine is low (15\%) due to extensive first-pass metabolism in the gastrointestinal mucosa and liver. It is rapidly absorbed via the oral mucosa after sublingual administration, but absorption into the systemic circulation is slow (maximum is 30 minutes to 3.5 hours after a single dose; one to two hours with repeat dosing; Elkader 2005). However, it does have a long duration of action (six to eight hours), which is thought to be due to an unusually slow dissociation constant for the drugreceptor complex. Naloxone is relatively ineffective in reversing opioid effects from buprenorphine, despite naloxone having high affinity for the mu-receptor (Gal 1989).

There was a ceiling effect for respiratory depression within the doses studied, but not for analgesia (Dahan 2005; Dahan 2006). While buprenorphine has been shown to slow intestinal transit, it possibly does this less than morphine (Bach 1991); importantly, constipation as an adverse effect may be less severe (Pace 2007). Buprenorphine also exerts little or no pressure on pancreatic and biliary ducts, distinguishing it from morphine in this respect (Staritz 1986). Compared with other opioids, buprenorphine causes little or no immunosuppression (Budd 2004; Sacerdote 2000; Sacerdote 2008). Buprenorphine does not accumulate in renal failure and it is not removed by haemodialysis, and analgesia is unaffected (Filitz 2006; Hand 1990).

Because buprenorphine is highly lipid-soluble, it is ideal for transdermal delivery. Buprenorphine patch preparations for twice weekly or weekly use are available with a range of transdermal drug delivery rates $(5,10,20,35,52.5,70 \mu \mathrm{g}$ /hour). NICE suggests that a transdermal buprenorphine patch of $20 \mu \mathrm{g} / \mathrm{hour}$ equates to approximately $30 \mathrm{mg}$ of oral morphine daily (NICE 2012). Buprenorphine via either the transdermal or injectable route is approved for managing moderate to severe chronic pain. Sublingual tablets and a sublingual film preparations are also available in some countries and are sometimes combined with naloxone. While these are usually used for the treatment of opioid addiction, some sublingual tablets $(200$ and $400 \mu \mathrm{g})$ without naloxone are available for chronic moderate to severe pain.

Transdermal buprenorphine has been suggested to be of value in treating chronic non-cancer pain (Kusnik 2008; Sittl 2005), including neuropathic pain after traumatic amputation, central neuropathic pain, and HIV neuropathy (Canneti 2013; Hakl 2012; Licina 2013; Weiner 2012). However, these are case reports, case series, or postmarketing analyses rather than randomised trials.

\section{How the intervention might work}

Opioids such as buprenorphine bind to specific opioid receptors in the nervous system and other tissues; there are three principal classes of receptors (mu, kappa, and delta) although others have been suggested, and subtypes of receptors are considered to exist. Binding of opioid agonists such as buprenorphine to receptors brings about complex cellular changes, outcomes of which include decreased perception of pain, decreased reaction to pain, and increased pain tolerance. Opioids from plant sources have been used for thousands of years to treat pain.

\section{Why it is important to do this review}

One UK survey found that weak and strong opioids were used frequently for treating neuropathic pain (Hall 2013). Many clinicians (primary care and pain specialists) consider that buprenorphine has an important place in the management of chronic pain conditions (Pergolizzi 2010). When compared with other opioids, buprenorphine has a better adverse effect and safety profile. Despite this, buprenorphine (patches in particular) is often 'blacklisted' on formularies, meaning that prescribing the drug is not approved or allowed. This is reported to be on the basis of lack of good-quality evidence. Since the early-2000s, a marked increase in prescribing of opioids for non-cancer pain in general despite a relatively modest evidence base has, in some countries, led to widespread diversion with consequent abuse, misuse, and mortality (Franklin 2014). Concurrently, suspicion has arisen that opioid-induced hyperalgesia, together with tolerance to the analgesic effects of opioids, may in reality result in a lesser degree of benefit for opioids in neuropathic pain than previously assumed.

The standards used to assess evidence in chronic pain trials have evolved substantially in recent years, with particular attention being paid to trial duration, withdrawals, and statistical imputation following withdrawal, all of which can substantially alter estimates of efficacy. The most important change is the move from using mean pain scores, or mean change in pain scores, to the number of people who have a large decrease in pain (by at least $50 \%$ ) and who continue in treatment, ideally in trials of eight to 12 weeks' duration or longer. Pain intensity reduction of $50 \%$ or more correlates with improvements in co-morbid symptoms, function, and quality of life. These standards are set out in the PaPaS Author and Referee Guidance for pain studies of the Cochrane Pain, Palliative and Supportive Care Group (PaPaS 2012).

This Cochrane review assessed evidence using methods that make both statistical and clinical sense, and used developing criteria for what constitutes reliable evidence in chronic pain (Moore 2010a). For inclusion and analysis, trials had to meet a minimum of reporting quality (blinding, randomisation), validity (duration, dose and timing, diagnosis, outcomes, etc), and size (ideally at least 500 participants in a comparison in which the NNT is 4 or above; Moore 1998). This approach sets high standards for the demonstration of efficacy and marks a departure from how reviews were conducted previously.

Taking this newer, more rigorous approach is particularly important for opioids in chronic non-cancer pain. Opioids in clinical trials in non-cancer pain are associated with very high withdrawal rates of up to $60 \%$ over about 12 weeks (Moore 2010b). Many withdrawals occur within the first few weeks, when people experience pain relief but cannot tolerate the drug. The common practice of using the last observed results carried forward to the end of the trial many weeks later (last observation carried forward (LOCF)) can, therefore, produce results based largely on people who are no longer in the trial, and who in the real world could not achieve pain relief because they could not take the tablets. The newer standards, outlined in Appendix 1, would not allow this and can produce very different results. For example, one large analysis of pooled data 
from trials in osteoarthritis and chronic low back pain conducted over about 12 weeks judged oxycodone effective, but an analysis of the same data using the new clinically meaningful standards showed it to be significantly worse than placebo (Lange 2010).

One previous Cochrane review demonstrated the limitations of our knowledge about opioids in neuropathic pain, except in short duration studies of 24 hours or less (McNicol 2013). These limitations were confirmed by a review specific to oxycodone (Gaskell 2014). A review specific to buprenorphine is timely.

\section{O B J E C T IVES}

To assess the analgesic efficacy of buprenorphine for chronic neuropathic pain in adults, and the adverse events associated with its use in clinical trials.

\section{MET HOD S}

\section{Criteria for considering studies for this review Types of studies}

We included randomised controlled trials (RCTs) with doubleblind assessment of participant outcomes following two weeks of treatment or longer, though the emphasis of the review was on studies of eight weeks or longer. We required full journal publication, with the exception of online clinical trial results summaries of otherwise unpublished clinical trials and abstracts with sufficient data for analysis. We did not include short abstracts (usually meeting reports). We excluded studies that were nonrandomised, studies of experimental pain, case reports, and clinical observations.

\section{Types of participants}

Studies included adults aged 18 years and above with one or more chronic neuropathic pain condition including (but not limited to):

1. cancer-related neuropathy;

2. central neuropathic pain;

3. complex regional pain syndrome (CRPS) Type II;

4. human immunodeficiency virus (HIV) neuropathy;

5. painful diabetic neuropathy (PDN);

6. phantom limb pain;

7. postherpetic neuralgia (PHN);

8. postoperative or traumatic neuropathic pain;

9. spinal cord injury;

10.trigeminal neuralgia.

Where studies included participants with more than one type of neuropathic pain, we planned to analyse results according to the primary condition.

\section{Types of interventions}

Buprenorphine at any dose, by any route, administered for the relief of neuropathic pain and compared with placebo or any active comparator.

\section{Types of outcome measures}

We anticipated that studies would use a variety of outcome measures, with the majority of studies using standard subjective scales (numerical rating scale (NRS) or visual analogue scale (VAS)) for pain intensity or pain relief, or both. We were particularly interested in Initiative on Methods, Measurement, and Pain Assessment in Clinical Trials (IMMPACT) definitions for moderate and substantial benefit in chronic pain studies (Dworkin 2008). These are defined as:

1. at least $30 \%$ pain relief over baseline (moderate);

2. at least $50 \%$ pain relief over baseline (substantial);

3. much or very much improved on Patient Global Impression of Change scale (PGIC; moderate);

4. very much improved on PGIC (substantial).

These outcomes are different from those used in many earlier reviews, concentrating as they do on dichotomous outcomes where pain responses do not follow a normal (Gaussian) distribution. People with chronic pain desire high levels of pain relief, ideally more than $50 \%$ pain intensity reduction, and ideally having no worse than mild pain (Moore 2013b; O'Brien 2010).

We planned to include a 'Summary of findings' table as set out in the author guide (PaPaS 2012). We have not included a 'Summary of findings' table because there was no useful information to include.

\section{Primary outcomes}

1. Participant-reported pain relief of $30 \%$ or greater.

2. Participant-reported pain relief of $50 \%$ or greater.

3. PGIC much or very much improved.

4. PGIC very much improved.

\section{Secondary outcomes}

1. Any pain-related outcome indicating some improvement.

2. Withdrawals due to lack of efficacy, adverse events, and for any cause.

3. Participants experiencing any adverse event.

4. Participants experiencing any serious adverse event. Serious adverse events typically include any untoward medical occurrence or effect that at any dose results in death, is lifethreatening, requires hospitalisation or prolongation of existing hospitalisation, results in persistent or significant disability or incapacity, is a congenital anomaly or birth defect, is an 'important medical event' that may jeopardise the person, or may require an intervention to prevent one of the above characteristics or consequences.

5. Specific adverse events, particularly somnolence and dizziness.

\section{Search methods for identification of studies}

\section{Electronic searches}

We search the following databases, without language restrictions.

1. Cochrane Central Register of Controlled Trials (CENTRAL, via the Cochrane Register of Studies Online database (CRSO)) to 11 June 2015.

2. MEDLINE (via Ovid) from 1946 to 11 June 2015.

3. EMBASE (via Ovid) from 1974 to 11 June 2015.

The search strategies for CENTRAL, MEDLINE, and EMBASE are listed in Appendix 2, Appendix 3, and Appendix 4, respectively. 


\section{Searching other resources}

We reviewed the bibliographies of any RCTs identified and review articles, and searched clinical trial databases (ClinicalTrials.gov (ClinicalTrials.gov) and World Health Organization International Clinical Trials Registry Platform (ICTRP) (apps.who.int/ trialsearch/)) to identify additional published or unpublished data. We did not contact investigators or study sponsors.

\section{Data collection and analysis}

We planned to perform separate analyses according to particular neuropathic pain conditions. We planned to combine different neuropathic pain conditions in analyses for exploratory purposes only.

\section{Selection of studies}

We determined eligibility by reading the abstract of each study identified by the search. We eliminated studies that clearly did not satisfy the inclusion criteria, and obtained full copies of the remaining studies. Two review authors made the decisions. Two review authors read these studies independently and reached agreement by discussion. We did not anonymise the studies in any way before assessment. We have included a Preferred Reporting Items for Systematic Reviews and Meta-Analyses (PRISMA) flow chart (Liberati 2009; Figure 1).

Figure 1. Study flow diagram.

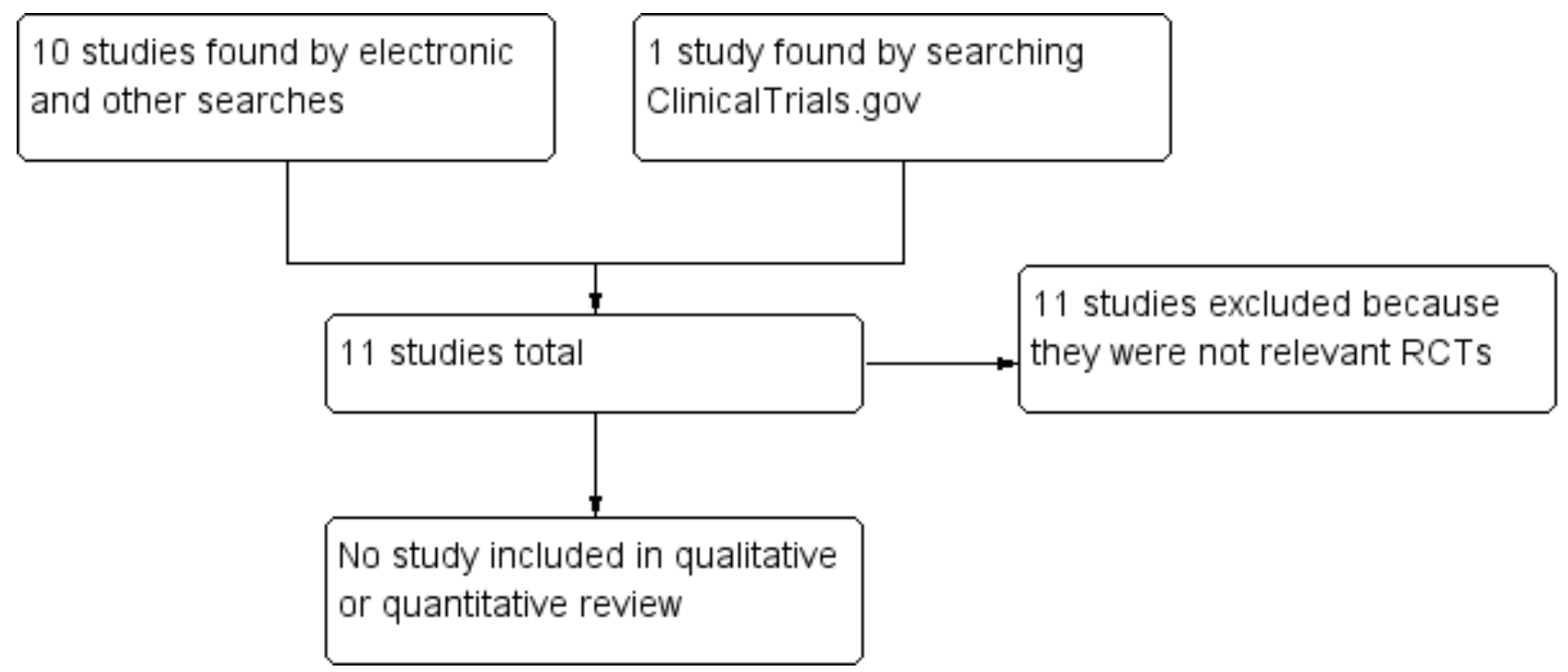

\section{Data extraction and management}

We planned that two review authors would extract data independently using a standard form and check for agreement before entry into Review Manager 5 (RevMan 2014), or any other analysis tool. We planned to include information about the pain condition and number of participants treated, drug and dosing regimen, study design (placebo or active control), study duration and follow-up, analgesic outcome measures and results, withdrawals, and adverse events (participants experiencing any adverse event or serious adverse event).

\section{Assessment of risk of bias in included studies}

We planned to use the Oxford Quality Score as the basis for inclusion (Jadad 1996), limiting inclusion to studies that are randomised and double-blind as a minimum.

Two review authors would have independently assessed risk of bias for each study, using the criteria outlined in the Cochrane Handbook for Systematic Reviews of Interventions (Higgins 2011), and adapted from those used by the Cochrane Pregnancy and Childbirth Group, with any disagreements resolved by discussion. We planned to assess the following for each study.

1. Random sequence generation (checking for possible selection bias). We planned to assess the method used to generate the allocation sequence as: low risk of bias (any truly random process, random number table, computer random number generator); unclear risk of bias (when the method used to generate the sequence is not clearly stated). We intended to exclude studies at a high risk of bias that used a non-random process (odd or even date of birth, hospital or clinic record number).

2. Allocation concealment (checking for possible selection bias). The method used to conceal allocation to interventions prior to assignment determines whether intervention allocation could have been foreseen in advance of, or during, recruitment, or changed after assignment. We planned to assess the methods as: low risk of bias (telephone or central randomisation, consecutively numbered, sealed, opaque envelopes); unclear risk of bias (when method not clearly stated). We intended to exclude studies that did not conceal allocation and were, therefore, at a high risk of bias (open list).

3. Blinding of outcome assessment (checking for possible detection bias). We planned to assess the methods used to blind study participants and outcome assessors from knowledge of which intervention a participant received. We planned to assess the methods as: low risk of bias (study stated that it was blinded and described the method used to achieve blinding, identical tablets, matched in appearance and smell); unclear risk of bias (study stated that it was blinded but did not provide an adequate 
description of how it was achieved). We intended to exclude studies at a high risk of bias that were not double-blind.

4. Incomplete outcome data (checking for possible attrition bias due to the amount, nature, and handling of incomplete outcome data). We planned to assess the methods used to deal with incomplete data as: low risk of bias (less than $10 \%$ of participants did not complete the study or used 'baseline observation carried forward' analysis, or both); unclear risk of bias (used LOCF analysis); or high risk of bias (used 'completer' analysis).

5. Size of study (checking for possible biases confounded by small size). We planned to assess studies as being at low risk of bias (200 participants or more per treatment arm); unclear risk of bias (50 to 199 participants per treatment arm); or high risk of bias (fewer than 50 participants per treatment arm).

\section{Measures of treatment effect}

We planned to calculate NNTs as the reciprocal of the absolute risk reduction (ARR; McQuay 1998). For unwanted effects, the NNT becomes the number needed to treat for an additional harmful outcome (NNH) and is calculated in the same manner. We planned to use dichotomous data to calculate risk ratio (RR) with $95 \%$ confidence intervals $(\mathrm{Cl})$ using a fixed-effect model unless we found significant statistical heterogeneity (see Assessment of heterogeneity). We planned not to use continuous data in analyses, and intended to extract and use continuous data, which probably reflects efficacy and utility poorly, only if useful for illustrative purposes only.

\section{Unit of analysis issues}

We accepted randomisation to individual participant only. We planned to split the control treatment arm between active treatment arms in a single study if the active treatment arms were not combined for analysis.

\section{Dealing with missing data}

We planned to use intention-to-treat (ITT) analysis where the ITT population consisted of participants who were randomised, took at least one dose of the assigned study medication, and provided at least one post-baseline assessment. We planned to assign zero improvement to missing participants wherever possible.

\section{Assessment of heterogeneity}

We planned to deal with clinical heterogeneity by combining studies that examined similar conditions. We planned to assess statistical heterogeneity visually (L'Abbé 1987), and using the 12 statistic. When the $\mathrm{I}^{2}$ value was greater than $50 \%$, we intended to consider possible reasons for this.

\section{Assessment of reporting biases}

The aim of this review was to use dichotomous outcomes of known utility and of value to people with pain (Hoffman 2010; Moore 2010c; Moore 2010d; Moore 2010e; Moore 2013b). The review would not depend on what the authors of the original studies chose to report or not, though clearly difficulties might arise in studies that did not report any dichotomous results.

We planned to assess publication bias using a method designed to detect the amount of unpublished data with a null effect required to make any result clinically irrelevant (usually taken to mean an NNT of 10 or higher; Moore 2008).

\section{Data synthesis}

We planned to use a fixed-effect model for meta-analysis. We would have used a random-effects model for meta-analysis if there was significant clinical heterogeneity and it was considered appropriate to combine studies.

We planned to analyse data for each neuropathic pain condition in three tiers, according to outcome and freedom from known sources of bias.

1. The first tier would use data meeting current best standards, where studies report the outcome of at least $50 \%$ pain intensity reduction over baseline (or its equivalent), without the use of LOCF or other imputation method for drop-outs, report an ITT analysis, last eight or more weeks, have a parallel-group design, and have at least 200 participants (preferably at least 400) in the comparison (Moore 1998; Moore 2010a; Moore 2012a; Moore 2012b). We would report these first-tier results first.

2. The second tier would use data from at least 200 participants but where one or more of the first-tier conditions above was not met (reporting at least 30\% pain intensity reduction, using LOCF or a completer analysis, or lasting four to eight weeks).

3. The third tier of evidence would relate to data from fewer than 200 participants, or where there were expected to be significant problems because, for example, of very short duration studies of less than four weeks; where there was major heterogeneity between studies; or where there were shortcomings in allocation concealment, attrition, or incomplete outcome data. For this third tier of evidence, no data synthesis is reasonable and may be misleading, but an indication of beneficial effects might be possible.

\section{Subgroup analysis and investigation of heterogeneity}

We planned to carry out analyses according to individual neuropathic pain conditions because placebo response rates for the same outcome can vary between conditions, as can the drugspecific effects (Moore 2009).

We did not plan subgroup analyses since experience of previous reviews indicated that there would be too few data for any meaningful subgroup analysis (Gaskell 2014; McNicol 2013).

\section{Sensitivity analysis}

We planned no sensitivity analysis because the evidence base was known to be too small to allow reliable analysis; we would not pool results from neuropathic pain of different origins in the primary analyses. We planned to examine details of doseescalation schedules in the unlikely situation that this could provide some basis for a sensitivity analysis.

\section{RE S U L T S}

\section{Description of studies}

\section{Results of the search}

Electronic searches identified 10 possible studies for inclusion, and searches of ClinicalTrials.gov identified one study. Figure 1 shows the flow diagram of study selection. No study matched the 
inclusion criteria. We did not identify any studies testing the effects of buprenorphine in neuropathic pain that satisfied our inclusion criteria.

\section{Included studies}

There were no included studies.

\section{Excluded studies}

We excluded 11 studies. Two were reviews with no primary clinical trial data (Kress 2009; Sittl 2005). Five were randomised trials, but included a mix of pain conditions, including musculoskeletal pain and cancer pain, and did not report results for the (often few) participants with neuropathic pain (Böhme 2003; Landau 2007; NCT00312195; Sittl 2003; Sorge 2004). Two were not double-blind (Canneti 2013; Penza 2008), one was not randomised (RodriguezLopez 2004), and one was a short duration study examining opioid conversion ratios in a small number of participants after surgery (Benedetti 1998).

\section{Risk of bias in included studies}

There were no studies to evaluate.

\section{Effects of interventions}

There were no studies to evaluate.

\section{DISCUSSION}

\section{Summary of main results}

We found no studies assessing the efficacy of buprenorphine in neuropathic pain to include in this review. Several studies, some randomised, had assessed buprenorphine, usually as a transdermal patch, in chronic pain. This was usually a mix of various types of pain, typically but not always with musculoskeletal pain predominating. None reported results by type of pain condition, and none of the studies provided a thorough assessment that any of the participants had pain with a neuropathic component. Using data from those studies would be little more than a guess.

As best we know, there is no evidence to support or refute the use of buprenorphine for treating neuropathic pain. This is despite the fact that one UK survey found that weak and strong opioids were used frequently for treating neuropathic pain, either alone or in combination with other drugs (Hall 2013). The lack of evidence for long-term benefit with buprenorphine reflects a similar result with oxycodone and other opioids (Gaskell 2014; McNicol 2013). The lack of evidence of efficacy combined with substantial evidence of harm has led to calls for referral to a pain management specialist (ideally with expertise in opioid use) if daily dosing exceeds 8 to $100 \mathrm{mg}$ morphine equivalents a day, particularly if pain and function are not substantially improved (Franklin 2014).

\section{Overall completeness and applicability of evidence}

There was no evidence for inclusion.

\section{Quality of the evidence}

There was no evidence for inclusion.

\section{Potential biases in the review process}

We know of no potential biases in the review process. It is unlikely that there is a large body of unpublished evidence showing a large effect from buprenorphine in neuropathic pain.

\section{Agreements and disagreements with other studies or reviews}

This review agrees with previous reviews and Cochrane reviews that there appear to be no clinical studies specifically assessing the efficacy of buprenorphine, at any dose or formulation, in neuropathic pain (Kress 2009; McNicol 2013).

\section{AUTHORS' CONCLUSIONS}

\section{Implications for practice}

\section{For people with neuropathic pain}

There is insufficient evidence to support or refute the suggestion that buprenorphine has any efficacy in any neuropathic pain condition.

\section{For clinicians}

There is insufficient evidence to support or refute the suggestion that buprenorphine has any efficacy in any neuropathic pain condition.

\section{For policy makers}

There is insufficient evidence to support or refute the suggestion that buprenorphine has any efficacy in any neuropathic pain condition. In the absence of any supporting evidence, it should probably not be recommended, except at the discretion of a pain specialist with particular expertise in opioid use.

\section{For funders}

There is insufficient evidence to support or refute the suggestion that buprenorphine has any efficacy in any neuropathic pain condition. In the absence of any supporting evidence, it should probably not be recommended, except at the discretion of a pain specialist with particular expertise in opioid use.

\section{Implications for research}

Large, robust randomised trials with patient-centred outcomes would be required to produce evidence to support or refute efficacy of buprenorphine in neuropathic pain. The necessary design of such trials is well established, but for opioids in neuropathic pain, the outcomes should be those of at least $30 \%$ and at least $50 \%$ pain intensity reduction over baseline at the end of a trial of 12 weeks' duration in participants continuing on treatment. Withdrawal for any reason should be regarded as treatment failure, and LOCF analysis should not be used. The reason for this is that, in chronic pain, opioids frequently produce withdrawal rates of $50 \%$ or more, meaning that LOCF analysis can overstate treatment efficacy.

\section{ACKNOWLEDGEMENTS}

Institutional support is provided by the Oxford Pain Relief Trust.

The National Institute for Health Research (NIHR) is the largest single funder of the Cochrane Pain, Palliative and Supportive Care Review Group. 
Disclaimer: the views and opinions expressed herein are those of the review authors and do not necessarily reflect those of the NIHR, National Health Service (NHS), or the Department of Health. 


\section{RE F E R E N C E S}

\section{References to studies excluded from this review}

Benedetti 1998 \{published data only\}

Benedetti F, Vighetti S, Amanzio M, Casadio C, Oliaro A, Bergamasco B, et al. Dose-response relationship of opioids in nociceptive and neuropathic postoperative pain. Pain 1998;74(2-3):205-11. [DOI: 10.1016/S0304-3959(97)00172-3]

\section{Böhme 2003 \{published data only\}}

Böhme K, Likar R. Efficacy and tolerability of a new opioid analgesic formulation, buprenorphine transdermal therapeutic system (TDS) in the treatment of patients with chronic pain. A randomised, double-blind, placebo-controlled study. Pain Clinic 2003;15:193-202. [DOI: 10.1163/156856903321579334]

\section{Canneti 2013 \{published data only\}}

Canneti A, Luzi M, Di Marco P, Cannata F, Pasqualitto F, Spinoglio A, et al. Safety and efficacy of transdermal buprenorphine and transdermal fentanyl in the treatment of neuropathic pain in AIDS patients. Minerva Anestesiologica 2013;79:871-83. [PUBMED: 23558760]

Kress 2009 \{published data only\}

Kress HG. Clinical update on the pharmacology, efficacy and safety of transdermal buprenorphine. European Journal of Pain 2009;13(3):219-30. [DOI: 10.1016/j.ejpain.2008.04.011]

\section{Landau 2007 \{published data only\}}

Landau CJ, Carr WD, Razzetti AJ, Sessler NE, Munera C, Ripa SR. Buprenorphine transdermal delivery system in adults with persistent noncancer-related pain syndromes who require opioid therapy: a multicenter, 5 -week run-in and randomized, double-blind maintenance-of-analgesia study. Clinical Therapeutics 2007;29(10):2179-93. [DOI: 10.1016/ j.clinthera.2007.10.010]

\section{NCT00312195 \{published data only\}}

Anon. Safety and efficacy of buprenorphine transdermal system (BTDS) in subjects with chronic nonmalignant pain, 2012. clinicaltrials.gov/ct2/show/NCT00312195 (accessed 11 June 2015).

\section{Penza 2008 \{published data only\}}

Penza P, Campanella A, Martini A, Melli G, Lombardi R, Camozzi F, et al. Short- and intermediate-term efficacy of buprenorphine TDS in chronic painful neuropathies. Journal of the Peripheral Nervous System 2008;13(4):283-8. [DOI: 10.1111/ j.1529-8027.2008.00194.x]

\section{Rodriguez-Lopez 2004 \{published data only\}}

Rodriguez-Lopez MJ, The Opioid Study Group of the Spanish Pain Society. Transdermal buprenorphine in the management of neuropathic pain. Revista de la Sociedad Española del Dolor 2004;11(Suppl V):11-21.

\section{Sittl 2003 \{published data only\}}

Sittl R, Griessinger N, Likar R. Analgesic efficacy and tolerability of transdermal buprenorphine in patients with inadequately controlled chronic pain related to cancer and other disorders: a multicenter, randomized, double-blind, placebo-controlled trial. Clinical Therapeutics 2003;25(1):150-68. [DOI: 10.1016/ S0149-2918(03)90019-1]

\section{Sittl 2005 \{published data only\}}

Sittl R. Transdermal buprenorphine in the treatment of chronic pain. Expert Reviews in Neurotherapeutics 2005;5(3):315-23. [DOI: 10.1586/14737175.5.3.315]

\section{Sorge 2004 \{published data only\}}

Sorge J, Sittl R. Transdermal buprenorphine in the treatment of chronic pain: results of a phase III, multicenter, randomized, double-blind, placebo-controlled study. Clinical Therapeutics 2004;26(11):1808-20. [10.10016/j clinthera,2004. 11008]

\section{Additional references}

\section{Bach 1991}

Bach V, Kamp-Jensen M, Jensen NH, Eriksen J. Buprenorphine and sustained release morphine - effect and side-effects in chronic use. Pain Clinic 1991;4:87-93.

\section{Baron 2012}

Baron R, Wasner G, Binder A. Chronic pain: genes, plasticity, and phenotypes. Lancet Neurology 2012;11(1):19-21. [DOI: 10.1016/ S1474-4422(11)70281-2]

\section{Bouhassira 2008}

Bouhassira D, Lantéri-Minet M, Attal N, Laurent B, Touboul C. Prevalence of chronic pain with neuropathic characteristics in the general population. Pain 2008;136(3):380-7. [DOI: 10.1016/ j.pain.2007.08.013]

\section{Budd 2004}

Budd K, Shipton E. Acute pain and the immune system and opioimmunosuppression. Acute Pain 2004;6:123-35.

\section{Bullingham 1981}

Bullingham RES, McQuay HJ, Dwyer D, Allen MC, Moore RA. Sublingual buprenorphine used post-operatively: clinical observations and preliminary pharmacokinetic analysis. British Journal of Clinical Pharmacology 1981;12:117-22. [PUBMED: 7306425 ]

\section{Bullingham 1983}

Bullingham RES, McQuay HJ, Moore RA. Clinical pharmacokinetics of narcotic agonist-antagonist drugs. Clinical Pharmacology 1983;8:332-43. [PUBMED: 6352139]

\section{Bullingham 1984}

Bullingham RE, Moore RA, Symonds HW, Allen MC, Baldwin D, McQuay HJ. A novel form of dependency of hepatic extraction ratio of opioids in vivo upon the portal vein concentration of drug: comparison of morphine, diamorphine, fentanyl, methadone and buprenorphine in the chronically cannulated cow. Life Sciences 1984;34(21):2047-56. [PUBMED: 6727551] 


\section{Calvo 2012}

Calvo M, Dawes JM, Bennett DL. The role of the immune system in the generation of neuropathic pain. Lancet Neurology 2012;11(7):629-42. [DOI: 10.1016/S1474-4422(12)70134-5]

\section{Dahan 2005}

Dahan A, Yassen A, Bijl H, Romberg R, Sarton E, Teppema L, et al. Comparison of the respiratory effects of intravenous buprenorphine and fentanyl in humans and rats. British Journal of Anaesthesia 2005;94(6):825-34. [DOI: 10.1093/bja/aei145]

\section{Dahan 2006}

Dahan A, Yassen A, Romberg R, Sarton E, Teppema L, Olofsen $\mathrm{E}$, et al. Buprenorphine induces ceiling in respiratory depression but not in analgesia. British Journal of Anaesthesia 2006;96(5):627-32. [DOI: 10.1093/bja/ael051]

\section{Demant 2014}

Demant DT, Lund K, Vollert J, Maier C, Segerdahl M, Finnerup NB, et al. The effect of oxcarbazepine in peripheral neuropathic pain depends on pain phenotype: a randomised, double-blind, placebo-controlled phenotype-stratified study. Pain 2014;155(11):2263-73. [DOI: 10.1016/j.pain.2014.08.014]

\section{Derry 2012}

Derry S, Moore RA. Topical capsaicin (low concentration) for chronic neuropathic pain in adults. Cochrane Database of Systematic Reviews 2012, Issue 9. [DOI: 10.1002/14651858.CD010111]

\section{Derry 2013}

Derry S, Sven-Rice A, Cole P, Tan T, Moore RA. Topical capsaicin (high concentration) for chronic neuropathic pain in adults. Cochrane Database of Systematic Reviews 2013, Issue 2. [DOI: 10.1002/14651858.CD007393.pub3]

\section{Derry 2014}

Derry S, Wiffen PJ, Moore RA, Quinlan J. Topical lidocaine for neuropathic pain in adults. Cochrane Database of Systematic Reviews 2014, Issue 7. [DOI: 10.1002/14651858.CD010958.pub2]

\section{Dworkin 2008}

Dworkin RH, Turk DC, Wyrwich KW, Beaton D, Cleeland CS, Farrar JT, et al. Interpreting the clinical importance of treatment outcomes in chronic pain clinical trials: IMMPACT recommendations. Journal of Pain 2008;9(2):105-21. [DOI: 10.1016/j.jpain.2007.09.005]

\section{Elkader 2005}

Elkader A, Sproule B. Buprenorphine: clinical pharmacokinetics in the treatment of opioid dependence. Clinical Pharmacokinetics 2005;44(7):661-80. [DOI: 10.2165/00003088-200544070-00001]

\section{Filitz 2006}

Filitz J, Griessinger N, Sittl R, Likar R, Schüttler J, Koppert W. Effect of intermittent hemodialysis on buprenorphine and norbuprenorphine plasma concentrations in chronic pain patients treated with transdermal buprenorphine. European Journal of Pain 2006;10(8):743-8. [DOI: 10.1016/ j.ejpain.2005.12.001]

\section{Finnerup 2013}

Finnerup NB, Scholz J, Attal N, Baron R, Haanpää M, Hansson P, et al. Neuropathic pain needs systematic classification. European Journal of Pain 2013;17(7):953-6. [DOI: 10.1002/ j.1532-2149.2012.00282.x]

\section{Finnerup 2015}

Finnerup NB, Attal N, Haroutounian S, McNicol E, Baron R, Dworkin RH, et al. Pharmacotherapy for neuropathic pain in adults: a systematic review and meta-analysis. Lancet Neurology 2015;14(2):162-73. [DOI: 10.1016/S1474-4422(14)70251-0]

\section{Foster 2013}

Foster B, Twycross R, Mihalyo M, Wilcock A. Buprenorphine therapeutic reviews. Journal of Pain and Symptom Management 2013;45(5):939-49. [DOI: 10.1016/j.jpainsymman.2013.03.001]

\section{Franklin 2014}

Franklin GM, American Academy of Neurology. Opioids for chronic noncancer pain: a position paper of the American Academy of Neurology. Neurology 2014;83(14):1277-84. [DOI: 10.1212/WNL.0000000000000839]

\section{Gal 1989}

Gal TJ. Naloxone reversal of buprenorphine-induced respiratory depression. Clinical Pharmacology and Therapeutics 1989;45(1):6-71. [PUBMED: 2491980]

\section{Gaskell 2014}

Gaskell H, Moore RA, Derry, S, Stannard C. Oxycodone for neuropathic pain and fibromyalgia in adults. Cochrane Database of Systematic Reviews 2014, Issue 6. [DOI: 10.1002/14651858.CD010692.pub2]

\section{Gustorff 2008}

Gustorff B, Dorner T, Likar R, Grisold W, Lawrence K, Schwarz F, et al. Prevalence of self-reported neuropathic pain and impact on quality of life: a prospective representative survey. Acta Anaesthesiologica Scandinavica 2008;52(1):132-6. [DOI: 10.1111/ j.1399-6576.2007.01486.x]

\section{Hakl 2012}

Hakl M. Transdermal buprenorphine in clinical practice: a multicenter, postmarketing study in the Czech Republic, with a focus on neuropathic pain components. Pain Management 2012;2(2):169. [DOI: 10.2217/pmt.11.92]

\section{Hall 2008}

Hall GC, Carroll D, McQuay HJ. Primary care incidence and treatment of four neuropathic pain conditions: a descriptive study, 2002-2005. BMC Family Practice 2008;9:26. [DOI: 10.1186/1471-2296-9-26]

\section{Hall 2013}

Hall GC, Morant SV, Carroll D, Gabriel ZL, McQuay HJ. An observational descriptive study of the epidemiology and treatment of neuropathic pain in a UK general population. $B M C$ Family Practice 2013;14:28. [DOI: 10.1186/1471-2296-14-28] 


\section{Hand 1990}

Hand CW, Sear JW, Uppington J, Ball MJ, McQuay HJ, Moore RA. Buprenorphine disposition in patients with renal impairment: single and continuous dosing, with special reference to metabolites. British Journal of Anaesthesia 1990;64(3):276-82.

\section{Helfert 2015}

Helfert SM, Reimer M, Höper J, Baron R. Individualized pharmacological treatment of neuropathic pain. Clinical Pharmacology and Therapeutics 2015;97(2):135-42. [DOI: 10.1002/cpt.19]

\section{Higgins 2011}

Higgins JPT, Altman DG, Sterne JAC. Chapter 8: Assessing risk of bias in included studies. In: Higgins JPT, Green S (editors). Cochrane Handbook for Systematic Reviews of Interventions Version 5.1.0 [updated March 2011]. The Cochrane Collaboration, 2011. Available from www.cochranehandbook.org.

\section{Hoffman 2010}

Hoffman DL, Sadosky A, Dukes EM, Alvir J. How do changes in pain severity levels correspond to changes in health status and function in patients with painful diabetic peripheral neuropathy?. Pain 2010;149(2):194-201. [DOI: 10.1016/ j.pain.2009.09.017]

\section{Jadad 1996}

Jadad AR, Moore RA, Carroll D, Jenkinson C, Reynolds DJ, Gavaghan DJ, et al. Assessing the quality of reports of randomized clinical trials: is blinding necessary? Controlled Clinical Trials 1996;17(1):1-12. [DOI: 10.1016/0197-2456(95)00134-4]

\section{Jensen 2011}

Jensen TS, Baron R, Haanpää M, Kalso E, Loeser JD, Rice AS, et al. A new definition of neuropathic pain. Pain 2011; Vol. 152, issue 10:2204-5. [DOI: 10.1016/j.pain.2011.06.017]

\section{Kalso 2013}

Kalso E, Aldington DJ, Moore RA. Drugs for neuropathic pain. BMJ 2013;347:f7339. [DOI: 10.1136/bmj.f7339]

\section{Katusic 1991}

Katusic S, Williams DB, Beard CM, Bergstralh EJ, Kurland LT. Epidemiology and clinical features of idiopathic trigeminal neuralgia and glossopharyngeal neuralgia: similarities and differences, Rochester, Minnesota, 1945-1984. Neuroepidemiology 1991;10:276-81. [DOI: 10.1159/000110284]

\section{Koopman 2009}

Koopman JS, Dieleman JP, Huygen FJ, de Mos M, Martin CG, Sturkenboom MC. Incidence of facial pain in the general population. Pain 2009;147(1-3):122-7. [DOI: 10.1016/ j.pain.2009.08.023]

\section{Kusnik 2008}

Kusnik S, Likar R, Sittl R. Transdermal buprenorphine in chronic pain: indications and clinical experience. Expert Review of Clinical Pharmacology. 2008;1(6):729-36. [DOI: 10.1586/17512433.1.6.729]

\section{L'Abbé 1987}

L'Abbé KA, Detsky AS, O'Rourke K. Meta-analysis in clinical research. Annals of Internal Medicine 1987;107:224-33.

\section{Lange 2010}

Lange B, Kuperwasser B, Okamoto A, Steup A, Häufel T, Ashworth J, et al. Efficacy and safety of tapentadol prolonged release for chronic osteoarthritis pain and low back pain. Advances in Therapy 2010;27(6):381-99. [DOI: 10.1007] s12325-010-0036-3]

\section{Liberati 2009}

Liberati A, Altman DG, Tetzlaff J, Mulrow C, Gøtzsche PC, loannidis JP, et al. The PRISMA statement for reporting systematic reviews and meta-analyses of studies that evaluate health care interventions: explanation and elaboration. Annals of Internal Medicine 2009;151(4):W65-94. [DOI: 10.7326/0003-4819-151-4-200908180-00136]

\section{Licina 2013}

Licina L, Hamsher C, Lautenschager K, Dhanjal S, Williams N, Spevak C. Buprenorphine/naloxone therapy for opioid refractory neuropathic pain following traumatic amputation: a case series. Military Medicine 2013;178(7):e858-61. [DOI: 10.7205/MILMED-D-12-00310]

\section{Lunn 2014}

Lunn MP, Hughes RA, Wiffen PJ. Duloxetine for treating painful neuropathy, chronic pain or fibromyalgia. Cochrane Database of Systematic Reviews 2014, Issue 1. [DOI: 10.1002/14651858.CD007115.pub3]

\section{McNicol 2013}

McNicol ED, Midbari A, Eisenberg E. Opioids for neuropathic pain. Cochrane Database of Systematic Reviews 2013, Issue 8. [DOI: 10.1002/14651858.CD006146.pub2]

\section{McQuay 1998}

McQuay H, Moore R. An Evidence-Based Resource for Pain Relief. Oxford: Oxford University Press, 1998. [ISBN: 0-19-263048-2]

\section{McQuay 2007}

McQuay HJ, Smith LA, Moore RA. Chronic pain. In: Stevens A, Raftery J, Mant J, Simpson S editor(s). Health Care Needs Assessment, 3rd Series. Oxford: Radcliffe Publishing, 2007. [ISBN: 978-1-84619-063-6]

\section{Moore 1998}

Moore RA, Gavaghan D, Tramèr MR, Collins SL, McQuay HJ. Size is everything - large amounts of information are needed to overcome random effects in estimating direction and magnitude of treatment effects. Pain 1998;78(3):209-16. [DOI: 10.1016/S0304-3959(98)00140-7]

\section{Moore 2008}

Moore RA, Barden J, Derry S, McQuay HJ. Managing potential publication bias. In: McQuay HJ, Kalso E, Moore RA editor(s). Systematic Reviews in Pain Research: Methodology Refined. Seattle: IASP Press, 2008:15-24. [ISBN: 978-0-931092-69-5] 


\section{Moore 2009}

Moore RA, Straube S, Wiffen PJ, Derry S, McQuay HJ. Pregabalin for acute and chronic pain in adults. Cochrane Database of Systematic Reviews 2009, Issue 3. [DOI: 10.1002/14651858.CD007076.pub2]

\section{Moore 2010a}

Moore RA, Eccleston C, Derry S, Wiffen P, Bell RF, Straube S, et al. "Evidence" in chronic pain - establishing best practice in the reporting of systematic reviews. Pain 2010;150(3):386-9. [DOI: 10.1016/j.pain.2010.05.011]

\section{Moore 2010b}

Moore RA, Straube S, Derry S, McQuay HJ. Chronic low back pain analgesic studies - a methodological minefield. Pain 2010;149(3):431-4. [DOI: 10.1016/j.pain.2010.02.032]

\section{Moore 2010c}

Moore RA, Straube S, Paine J, Phillips CJ, Derry S, McQuay HJ. Fibromyalgia: moderate and substantial pain intensity reduction predicts improvement in other outcomes and substantial quality of life gain. Pain 2010;149(2):360-4. [DOI: 10.1016/j.pain.2010.02.039]

\section{Moore 2010d}

Moore RA, Smugar SS, Wang H, Peloso PM, Gammaitoni A. Numbers-needed-to-treat analyses - do timing, dropouts, and outcome matter? Pooled analysis of two randomized, placebocontrolled chronic low back pain trials. Pain 2010;151(3):592-7. [DOI: 10.1016/j.pain.2010.07.013]

\section{Moore 2010e}

Moore RA, Moore OA, Derry S, Peloso PM, Gammaitoni AR, Wang $\mathrm{H}$. Responder analysis for pain relief and numbers needed to treat in a meta-analysis of etoricoxib osteoarthritis trials: bridging a gap between clinical trials and clinical practice. Annals of the Rheumatic Diseases 2010;69(2):374-9. [DOI: 10.1136/ard.2009.107805]

\section{Moore 2011a}

Moore RA, Straube S, Paine J, Derry S, McQuay HJ. Minimum efficacy criteria for comparisons between treatments using individual patient meta-analysis of acute pain trials: examples of etoricoxib, paracetamol, ibuprofen, and ibuprofen/ paracetamol combinations after third molar extraction. Pain 2011;152(5):982-9. [DOI: 10.1016/j.pain.2010.11.030]

\section{Moore 2011b}

Moore RA, Mhuircheartaigh RJ, Derry S, McQuay HJ. Mean analgesic consumption is inappropriate for testing analgesic efficacy in post-operative pain: analysis and alternative suggestion. European Journal of Anaesthesiology 2011;28(6):427-32. [DOI: 10.1097/EJA.0b013e328343c569]

\section{Moore 2012a}

Moore RA, Derry S, Aldington D, Cole P, Wiffen PJ. Amitriptyline for neuropathic pain and fibromyalgia in adults. Cochrane Database of Systematic Reviews 2012, Issue 12. [DOI: 10.1002/14651858.CD008242.pub2]

\section{Moore 2012b}

Moore RA, Straube S, Eccleston C, Derry S, Aldington D, Wiffen P, et al. Estimate at your peril: imputation methods for patient withdrawal can bias efficacy outcomes in chronic pain trials using responder analyses. Pain 2012;153(2):265-8. [DOI: 10.1016/j.pain.2011.10.004]

\section{Moore 2013a}

Moore A, Derry S, Eccleston C, Kalso E. Expect analgesic failure; pursue analgesic success. BMJ 2013;346:f2690. [DOI: 10.1136/ bmj.f2690]

\section{Moore 2013b}

Moore RA, Straube S, Aldington D. Pain measures and cut-offs - 'no worse than mild pain' as a simple, universal outcome. Anaesthesia 2013;68(4):400-12. [DOI: 10.1111/anae.12148]

\section{Moore 2014a}

Moore RA, Derry S, Taylor RS, Straube S, Phillips CJ. The costs and consequences of adequately managed chronic non-cancer pain and chronic neuropathic pain. Pain Practice 2014;14(1):79-94. [DOI: 10.1111/papr.12050]

\section{Moore 2014b}

Moore RA, Wiffen PJ, Derry S, McQuay HJ. Gabapentin for chronic neuropathic pain and fibromyalgia in adults. Cochrane Database of Systematic Reviews 2014, Issue 4. [DOI: 10.1002/14651858.CD007938.pub3]

\section{Moore 2014c}

Moore RA, Cai N, Skljarevski V, Tölle TR. Duloxetine use in chronic painful conditions - individual patient data responder analysis. European Journal of Pain 2014;18(1):67-75. [DOI: 10.1002/j.1532-2149.2013.00341.x]

\section{NICE 2012}

National Institute for Health and Care Excellence (NICE). Opioids in palliative care, 2012. www.nice.org.uk/guidance/cg140 (accessed 11 June 2015).

\section{NICE 2013}

National Institute for Health and Care Excellence (NICE) Neuropathic pain - pharmacological management: the pharmacological management of neuropathic pain in adults in non-specialist settings, 2013. www.nice.org.uk/guidance/cg173 (accessed 11 June 2015).

\section{O'Brien 2010}

O'Brien EM, Staud RM, Hassinger AD, McCulloch RC, Craggs JG, Atchison JW, et al. Patient-centered perspective on treatment outcomes in chronic pain. Pain Medicine 2010;11(1):6-15. [DOI: 10.1111/j.1526-4637.2009.00685]

\section{Pace 2007}

Pace MC, Passavanti MB, Grella E, Mazzariello L, Maisto M, Barbarisi M, et al. Buprenorphine in long-term control of chronic pain in cancer patients. Frontiers in Bioscience 2007;12:1291-9. [PUBMED: 17127381$]$ 


\section{PaPaS 2012}

Cochrane Pain, Palliative and Supportive Care Group (PaPaS) author and referee guidance. papas.cochrane.org/papasdocuments (accessed 11 June 2015).

\section{Pergolizzi 2010}

Pergolizzi J, Aloisi AM, Dahan A, Filitz J, Langford R, Likar R, et al. Current knowledge of buprenorphine and its unique pharmacological profile. Pain Practice 2010;10(5):428-60. [DOI: 10.1111/j.1533-2500.2010.00378.x]

\section{Rappaport 1994}

Rappaport ZH, Devor M. Trigeminal neuralgia: the role of self-sustaining discharge in the trigeminal ganglion. Pain 1994:56:127-38. [DOI: 10.1016/0304-3959(94)90086-8]

\section{RevMan 2014 [Computer program]}

The Nordic Cochrane Centre, The Cochrane Collaboration. Review Manager (RevMan). Version 5.3. Copenhagen: The Nordic Cochrane Centre, The Cochrane Collaboration, 2014.

\section{Sacerdote $\mathbf{2 0 0 0}$}

Sacerdote P, Bianchi M, Gaspani L, Manfredi B, Maucione A, Terno $\mathrm{G}$, et al. The effects of tramadol and morphine on immune responses and pain after surgery in cancer patients. Anesthesia \& Analgesia 2000;90(6):1411-4. [DOI: 10.1097/00000539-200006000-00028]

\section{Sacerdote 2008}

Sacerdote P, Franchi S, Gerra G, Leccese V, Panerai AE, Somaini L. Buprenorphine and methadone maintenance treatment of heroin addicts preserves immune function. Brain, Behavior, and Immunity 2008;22(4):606-13. [DOI: 10.1016] j.bbi.2007.12.013]

\section{Staritz 1986}

Staritz M, Poralla T, Manns M, Meyer Zum Büschenfelde KH. Effect of modern analgesic drugs (tramadol, pentazocine and buprenorphine) on the bile duct sphincter in man. Gut 1986;27(5):567-9. [PUBMED: 3699566]

\section{Straube 2008}

Straube S, Derry S, McQuay HJ, Moore RA. Enriched enrolment: definition and effects of enrichment and dose in trials of pregabalin and gabapentin in neuropathic pain. A systematic review. British Journal of Clinical Pharmacology 2008;66(2):266-75. [DOI: 10.1111/j.1365-2125.2008.03200]

\section{Straube 2010}

Straube S, Derry S, Moore RA, Paine J, McQuay HJ. Pregabalin in fibromyalgia - responder analysis from individual patient data. BMC Musculoskeletal Disorders 2010;11:150. [DOI: 10.1186/1471-2474-11-150]

\section{Sultan 2008}

Sultan A, Gaskell H, Derry S, Moore RA. Duloxetine for painful diabetic neuropathy and fibromyalgia pain: systematic review of randomised trials. BMC Neurology 2008;8:29. [DOI: 10.1186/1471-2377-8-9]

\section{Torrance 2006}

Torrance N, Smith BH, Bennett MI, Lee AJ. The epidemiology of chronic pain of predominantly neuropathic origin. Results from a general population survey. Journal of Pain 2006;7(4):281-9. [DOI: 10.1016/j.jpain.2005.11.008]

\section{Treede 2008}

Treede RD, Jensen TS, Campbell JN, Cruccu G, Dostrovsky JO, Griffin JW, et al. Neuropathic pain: redefinition and a grading system for clinical and research purposes. Neurology 2008;70(18):1630-5. [DOI: 10.1212/01.wnl.0000282763.29778.59]

\section{van Hecke 2014}

van Hecke O, Austin SK, Khan RA, Smith BH, Torrance N. Neuropathic pain in the general population: a systematic review of epidemiological studies. Pain 2014;155(4):654-62. [DOI: 10.1016/j.pain.2013.11.013]

\section{von Hehn 2012}

von Hehn CA, Baron R, Woolf CJ. Deconstructing the neuropathic pain phenotype to reveal neural mechanisms. Neuron 2012;73(4):638-52. [DOI: 10.1016/j.neuron.2012.02.008]

\section{Vos 2012}

Vos T, Flaxman AD, Naghavi M, Lozano R, Michaud C, Ezzati M, et al. Years lived with disability (YLDs) for 1160 sequelae of 289 diseases and injuries 1990-2010: a systematic analysis for the Global Burden of Disease Study 2010. Lancet 2012;380(9859):2163-96. [DOI: 10.1016/S0140-6736(12)61729-2]

\section{Walsh 2003}

Walsh SL, Eissenberg T. The clinical pharmacology of buprenorphine: extrapolating from the laboratory to the clinic. Drug and Alcohol Dependence 2003;70(2 Suppl):S13-27. [DOI: 10.1016/S0376-8716(03)00056-5]

\section{Weiner 2012}

Weiner M, Sarantopoulos C, Gordon E. Transdermal buprenorphine controls central neuropathic pain. Journal of Opioid Management 2012;8(6):414-5. [DOI: 10.5055/ jom.2012.0141]

\section{WHO 1996}

World Health Organization (WHO). Cancer pain relief, 1996. whqlibdoc.who.int/publications/9241544821.pdf (accessed 11 June 2015). [ISBN: 924154482 1]

\section{Wiffen 2013}

Wiffen PJ, Derry S, Moore RA, Aldington D, Cole P, Rice ASC, et al. Antiepileptic drugs for neuropathic pain and fibromyalgia - an overview of Cochrane reviews. Cochrane Database of Systematic Reviews 2013, Issue 11. [DOI: 10.1002/14651858.CD010567.pub2] 
CHARACTERISTICS OF STUDIES

Characteristics of excluded studies [ordered by study ID]

\begin{tabular}{ll}
\hline Study & Reason for exclusion \\
\hline Benedetti 1998 & $\begin{array}{l}\text { Not randomised comparison of buprenorphine versus placebo; intravenous buprenorphine; short } \\
\text { term }\end{array}$ \\
\hline Böhme 2003 & Various chronic pain diagnoses, plus cancer \\
\hline Canneti 2013 & Not double-blind \\
\hline Kress 2009 & Review \\
\hline Landau 2007 & 75\% of participants had pain of back, knee, or hip. Not neuropathic pain \\
\hline NCT00312195 & Non-cancer pain, without separate description of neuropathic pain \\
\hline Penza 2008 & Not double-blind \\
\hline Rodriguez-Lopez 2004 & Not a randomised controlled trial \\
\hline Sittl 2003 & Fewer than 20\% participants had neuropathic pain, not separately described \\
\hline Sittl 2005 & Review \\
\hline Sorge 2004 & Various chronic pain diagnoses, plus cancer \\
\hline
\end{tabular}

\section{AP P E N D I CES}

\section{Appendix 1. Methodological considerations for chronic pain}

There have been several changes in how the efficacy of conventional and unconventional treatments is assessed in chronic painful conditions. The outcomes are now better defined, particularly with new criteria for what constitutes moderate or substantial benefit (Dworkin 2008); older trials may only report participants with 'any improvement'. Newer trials tend to be larger, avoiding problems from the random play of chance. Newer trials also tend to be of longer duration, up to 12 weeks, and longer trials provide a more rigorous and valid assessment of efficacy in chronic conditions. New standards have evolved for assessing efficacy in neuropathic pain, and we are now applying stricter criteria for the inclusion of trials and assessment of outcomes, and are more aware of problems that may affect our overall assessment. To summarise some of the recent insights that must be considered in this new review.

1. Pain results tend to have a U-shaped distribution rather than a bell-shaped distribution. This is true in acute pain (Moore 2011a; Moore 2011b), back pain (Moore 2010d), and arthritis (Moore 2010e), as well as in fibromyalgia (Straube 2010); in all cases, average results usually describe the experience of almost no-one in the trial. Data expressed as averages are potentially misleading, unless they can be proven to be suitable.

2. As a consequence, we have to depend on dichotomous results (the individual either has or does not have the outcome) usually from pain changes or patient global assessments. The Initiative on Methods, Measurement, and Pain Assessment in Clinical Trials (IMMPACT) group has helped with their definitions of minimal, moderate, and substantial improvement (Dworkin 2008). In arthritis, trials of less than 12 weeks' duration, and especially those shorter than eight weeks, overestimate the effect of treatment (Moore 2010d); the effect is particularly strong for less effective analgesics, and this may also be relevant in neuropathic-type pain.

3. The proportion of people with at least moderate benefit can be small, even with an effective medicine, falling from $60 \%$ with an effective medicine in arthritis to 30\% in fibromyalgia (Moore 2009; Moore 2010d; Moore 2010e; Moore 2013a; Moore 2014c; Straube 2008; Sultan 2008). One Cochrane review of pregabalin in neuropathic pain and fibromyalgia demonstrated different response rates for different types of chronic pain (higher in painful diabetic neuropathy and postherpetic neuralgia and lower in central pain and fibromyalgia) (Moore 2009). This indicates that different neuropathic pain conditions should be treated separately from one another, and that pooling should not be done unless there are good reasons for doing so. 
4. Individual patient analyses indicate that people who get good pain relief (moderate or better) have major benefits in many other outcomes, affecting quality of life in a significant way (Moore 2010c; Moore 2014a).

5. Imputation methods such as last observation carried forward (LOCF), used when participants withdraw from clinical trials, can overstate drug efficacy especially when adverse event withdrawals with drug are greater than those with placebo (Moore 2012b).

\section{Appendix 2. Search strategy for CENTRAL (via CRSO)}

1. MESH DESCRIPTOR Neuralgia EXPLODE ALL TREES (608)

2. MESH DESCRIPTOR Peripheral Nervous System Diseases EXPLODE ALL TREES (2574)

3. MESH DESCRIPTOR Somatosensory Disorders EXPLODE ALL TREES (706)

4. ((pain ${ }^{\star}$ or discomfort $\left.{ }^{\star}\right)$ adj10 (central or complex or nerv* or neuralg* or neuropath*)):TI,AB,KY (3001)

5. ((neur ${ }^{\star}$ or nerv $\left.{ }^{\star}\right)$ adj6 (compress ${ }^{\star}$ or damag $\left.\left.{ }^{\star}\right)\right): \mathrm{TI}, \mathrm{AB}, \mathrm{KY}(599)$

6. 1 or 2 or 3 or 4 or $5(6020)$

7. MESH DESCRIPTOR Buprenorphine EXPLODE ALL TREES (625)

8. ((Buprenorphine or Buprenex or BuTrans or Norspan or Temgesic or Transtec)):TI,AB,KY (1295)

9. 7 or 8 (1295)

10.6 and $9(21)$

\section{Appendix 3. Search strategy for MEDLINE via Ovid}

1. $\operatorname{exp~NEURALGIA/~(14321)~}$

2. $\exp$ PERIPHERAL NERVOUS SYSTEM DISEASES/ (119844)

3. exp SOMATOSENSORY DISORDERS/ (17012)

4. ((pain ${ }^{\star}$ or discomfort ${ }^{\star}$ ) adj10 (central or complex or nerv* or neuralg* or neuropath $\left.{ }^{\star}\right)$ ).mp. (40873)

5. ((neur ${ }^{\star}$ or nerv $\left.{ }^{\star}\right)$ adj6 (compress ${ }^{\star}$ or damag $\left.\left.{ }^{\star}\right)\right) . m p . ~(50069)$

6. 1 or 2 or 3 or 4 or 5 (191840)

7. Buprenorphine/ (3941)

8. (Buprenorphine or Buprenex or BuTrans or Norspan or Temgesic or Transtec).mp. (4795)

9. 7 or 8 (4795)

10.randomized controlled trial.pt. (396566)

11.randomized.ab. (293430)

12.placebo.ab. (152783)

13.drug therapy.fs. (1780700)

14.randomly.ab. (206823)

15.trial.ab. (302884)

16.groups.ab. (1317074)

17.10 or 11 or 12 or 13 or 14 or 15 or 16 (3327371)

18.6 and 9 and 17 (121)

\section{Appendix 4. Search strategy for EMBASE (via Ovid)}

1. $\exp$ NEURALGIA/ (78460)

2. exp PERIPHERAL NERVOUS SYSTEM DISEASES/ (53324)

3. exp SOMATOSENSORY DISORDERS/ (69024)

4. ((pain ${ }^{\star}$ or discomfort ${ }^{\star}$ ) adj10 (central or complex or nerv ${ }^{\star}$ or neuralg* or neuropath*)).mp. (77046)

5. ((neur ${ }^{\star}$ or nerv $\left.{ }^{\star}\right)$ adj6 (compress ${ }^{\star}$ or damag $\left.\left.{ }^{\star}\right)\right) . m p .(70821)$

6. 1 or 2 or 3 or 4 or 5 (224936)

7. Buprenorphine/ (10243)

8. (Buprenorphine or Buprenex or BuTrans or Norspan or Temgesic or Transtec).mp. (12814)

9. 7 or 8 (12814)

10.random*.ti,ab. (990144)

11. factorial* ${ }^{*}$ ti,ab. (25655)

12. (crossover ${ }^{\star}$ or cross over $^{\star}$ or cross-over $\left.{ }^{\star}\right)$.ti,ab. (76470)

13.placebo*.ti,ab. (220414)

14. (doubl* adj blind $\left.{ }^{\star}\right)$.ti,ab. (157712)

15.assign ${ }^{\star}$.ti,ab. (265127) 
16. allocat ${ }^{\star} . \mathrm{ti}, \mathrm{ab}$. (94646)

17.RANDOMIZED CONTROLLED TRIAL.sh. (375450)

18.DOUBLE-BLIND PROCEDURE.sh. (123303)

19.CROSSOVER PROCEDURE.sh. (43118)

20.10 or 11 or 12 or 13 or 14 or 15 or 16 or 17 or 18 or 19 (1415101)

21.6 and 9 and 20 (139)

WHAT'S NEW

\begin{tabular}{lll}
\hline Date & Event & Description \\
\hline 28 May 2019 & Amended & Contact details updated. \\
\hline 11 October 2017 & Review declared as stable & No new studies likely to change the conclusions are expected. \\
\hline
\end{tabular}

\section{H I S T O R Y}

Protocol first published: Issue 3, 2015

Review first published: Issue 9, 2015

\begin{tabular}{lll}
\hline Date & Event & Description \\
\hline 7 June 2017 & Review declared as stable & See Published notes. \\
\hline
\end{tabular}

\section{CONTRIBUTIONS OF AUTHORS}

SD and RAM wrote the protocol.

SD, PW, and RAM searched for and selected studies for inclusion, and carried out data extraction.

All review authors were involved in writing the full review.

RAM will be responsible for any updates required.

\section{DECLARATIONS OF INTEREST}

PW has no conflicts relating to this review or any similar product.

SD has no conflicts relating to this review or any similar product.

RAM has no conflicts relating to this review or any similar product.

CS has no conflicts relating to this review or any similar product.

DA has no conflicts relating to this review or any similar product.

PC has no conflicts relating to this review or any similar product.

RK has no conflicts relating to this review or any similar product.

We are funded by the NIHR for work on a series of reviews informing the unmet need of chronic pain and providing the evidence for treatments of pain. 


\section{SOURCES OF SUPPORT}

\section{Internal sources}

- Oxford Pain Relief Trust, UK.

General institutional support

\section{External sources}

- The National Institute for Health Research (NIHR), UK.

NIHR Cochrane Programme Grant: 13/89/29 - Addressing the unmet need of chronic pain: providing the evidence for treatments of pain

\section{DIFFERENCES BETWEEN PROTOCOLANDREVIEW}

The protocol included both CRPS I and CRPS II as a diagnosis of neuropathic pain. We have now removed CRPS I because it is no longer considered to be neuropathic pain. There were no studies in CRPS I.

\section{NOTES}

A restricted search in June 2017 did not identify any potentially relevant studies likely to change the conclusions. We are not aware of any ongoing studies in this area. Therefore, this review has now been stabilised following discussion with the authors and editors. If appropriate, we will update the review if new evidence likely to change the conclusions is published, or if standards change substantially which necessitate major revisions.

\section{N DEX TERMS}

\section{Medical Subject Headings (MeSH)}

Analgesics, Opioid [*therapeutic use]; Buprenorphine [*therapeutic use]; Neuralgia [ ${ }^{\star}$ drug therapy]

\section{MeSH check words}

Adult; Humans 